Jumatald

Family

History

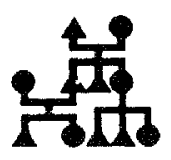

\title{
FAMILY AND SCHOOLING IN COLONIAL AND NINETEENTH-CENTURY AMERICA
}

\author{
Maris A. Vinovskis
}

\begin{abstract}
Throughout the seventeenth, eighteenth, and nineteenth centuries, both parents and schools played an important part in the education of young Americans. While historians of the family and of education have frequently acknowledged these complementary, if not sometimes conflicting, institutions in the training of the young, very little effort has been made to examine the interactions between them. The family was an important source of education for children in colonial and nineteenthcentury America. But from the very beginning churches and schools were directed to assist parents in the socialization of the young. Indeed, by the mid-nineteenth century, the role of the schools had expanded to such an extent that many of the educational tasks initially assigned to parents, such as teaching children the alphabet and how to read, became the responsibility of the schools.
\end{abstract}

Twenty-five years ago Bailyn (1960) called for a new and broader interepretation of American colonial educational development - one that recognized the important historical role of the family in the transmission of culture from one generation to the next. While many of the specific elements of his analysis need to be reconsidered and revised in light of subsequent

Journal of Family History

Volume 12, Numbers 1-3, pages 19-37

Copyright $\odot 1987$ by JAI Press Inc.

All rights of reproduction in any form reserved. ISSN: 0363-1990. scholarship, Bailyn's challenge to historians to study the interactions between the family and schooling in the socialization of the young continues to inspire and guide researchers.

Maris A. Vinovskis, Professor in the Department of History at the University of Michigan, Ann Arbor, Mich., 48109, has just published The Origins of Public High Schools: A Reexamination of the Beverly High School Controversy (University of Wisconsin Press, 1985), and is now completing An Epidemic of Adolescent Pregnancy? Some Historical and Policy Considerations (Oxford University Press, forthcoming). 
Despite the wide circulation and acceptance of Bailyn's essays on education in early America, few scholars have written directly on the relationship between the family and schooling-especially for the nineteenth century. Instead, most historians have analyzed particular facets of colonial and nineteenth-century family life or educational development without much explicit attention to the interactions between them. ${ }^{1}$ This article will attempt to briefly survey some of the more recent findings in the fields of American family and educational history from the perspective of the changing relationship between the family and schools in the seventeenth, eighteenth, and nineteenth centuries. Rather than providing a detailed review or a comprehensive synthesis of the large number of studies in each field, this article hopes to create a stimulus for further research by exploring some of the more salient points raised in those studies. Furthermore, while some references will be made to educational developments throughout all of the United States, most of the attention will be focused on New England because of the greater availability of secondary analyses relating to family and education in that region.

\section{FAMILY AND SCHOOLING IN COLONIAL AMERICA}

Bailyn's (1960) seminal book on early American educational development is based upon several assumptions about the nature of English society on the eve of colonization and the transformation of the American family in the inhospitable environment of the New World. English families were seen as patriarchal and extended:

The family familiar to the early colonists was a patrilineal group of extended kinship gathered in a single household. By modern standards it was large. Besides children, who often remained in the home well into maturity, it included a wide range of other dependents: nieces and nephews, cousins, and, except for families of the lowest rung of society, servants in filial discipline. In the Elizabethan family the conjugal was only the nucleus of a broad kinship community whose outer edges merged almost imperceptibly into the society at large (Bailyn, 1960: 15-16).

These patriarchal families and the larger communities were the central agencies for the socialization and education of children. Formal schools were not readily available or particularly important, but the church played a key role in educating the young. "Family, community, and church together accounted for the greater part of the mechanism by which English culture transferred itself across the generations. The instruments of deliberate pedagogy, of explicit, literate education, accounted for a smaller, though indispensable, portion of the process" (Bailyn, 1960: 18-19).

Settlers coming to the New World did not anticipate any major changes in the way children were raised and educated. Yet within a few decades the colonists, particularly in Puritan New England, had to reconceptualize and reorder their system of educating the young. Central to this change was the unexpected destruction of the stable, extended English family:

In many ways the most important changes, and certainly the most dramatic, were those that overtook the family in colonial America. In the course of these changes the family's traditional role as the primary agency of cultural transfer was jeopardized, reduced, and partly superseded.

Disruption and transplantation in alien soil transformed the character of the traditional English family life. Severe pressures were felt from the first. Normal procedures were upset by the long and acute discomforts of travel; the ancient discipline slackened. But once re-established in permanent settlements the colonists moved toward re- 
creating the essential institution in its usual form. In this, despite heroic efforts, they failed. At first they laid their failure to moral disorder; but in time they came to recognize its true source in the intractable circumstances of material life (Bailyn, 1960: 22).

In reasoning reminiscent of Handlin's (1951) analysis of nineteenth-century immigration, Bailyn argued that the role of children in the new environment was greatly enhanced at the expense of parental authority. ${ }^{2}$ As a result, the civil authorities intervened to try to prop up the weakened and endangered family and required communities in Massachusetts to maintain local schools to educate children who were no longer being properly trained within the family. Thus, for Bailyn the demise of the stable, extended English family in the New World led to the establishment of elementary schools - an unexpected but crucial step in the long-term development of schooling in America.

In the two decades since the publication of Bailyn's interpretation of family life and education, much more has been learned about English society in the sixteenth and seventeenth centuries. Contrary to Bailyn's assumption that most English families were extended and geographically immobile, it appears that English families were much smaller and predominantly nuclear (Houlbrooke, 1984; Laslett, 1969, 1972, 1977). While there is still controversy over the exact extent of extended families as seen from a more dynamic view of family life (Berkner, 1972; Vinovskis, forthcoming [a] , there is general agreement that most English families in the sixteenth and seventeenth centuries were nuclear with fewer than five members present at any given time. In addition, although a few families remained in the same community over several generations, there was much more geographic mobility than Bailyn had assumed (Prest, 1976).
Similarly, in the area of education, the availability of formal schooling in England in the sixteenth and seventeenth centuries appears to have been greater than Bailyn portrayed. In the mid-1960s Stone (1964) argued that the extent of schooling and literacy in England in the seventeenth century was considerably higher than scholars had previously acknowledged. More recent work on English education (O'Day, 1982) suggests that the improvements in education and literacy were more gradual than suggested by Stone, but accepts his notion of the relatively high rates of schooling and literacy in England on the eve of North American colonization.

If Bailyn exaggerated the stability, size, and complexity of English families and underestimated the extent of formal schooling, he also overestimated the disruption of family life in the New Worldespecially in New England which was the pioneer in establishing local schools. Studies of the migration of settlers to Massachusetts (Allen, 1981; Powell, 1963), for example, emphasize either the continuation of many English customs and practices or a more orderly process of adjustment to the new environment than the more cataclysmic picture portrayed by Bailyn. Indeed, Greven (1970), one of Bailyn's own students, found that parental authority in seventeenth-century Andover, Massachusetts was stronger and family life more stable than in England.

\footnotetext{
The remarkable success with which Andover's first generation rerooted themselves in the soil of the New England and maintained their families for generations to come reflects the opportunities for the establishment of orderly and cohesive families and communities in the midst of the American wilderness. In no significant sense were the lives of the first and second generations in disorder, once their permanent roots had been firmly established in early Andover (Greven, 1970: 271$)^{3}$
} 
As a result, Bailyn's claim that the sudden and unexpected disintegration and transformation of the family in the New World led to the creation of schools no longer seems as convincing and compelling as when it was first proposed twenty-five years ago.

Yet if Bailyn's specific explanations for the development of colonial education no longer appear as satisfactory, his emphasis on the importance of the family and the church for the education of the young in England was well-founded. Protestants in England generally promoted household religion and the Puritans emphasized it more than other religious groups (Axtell, 1974; Morgan, 1966). The Puritans assumed that the family had the primary responsibility for education and that the state would only intervene when the family failed to instruct its members in reading and religion. Hence, the late Renaissance in England was a time of expanding familial responsibility for education while also a period of school expansion. Rather than the establishment of schools being a substitute for household education (Ariès, 1962), the two processes were complementary (Cremin, 1970).

In the New World, the role of the family in educating the young was even more important than in England - partly out of necessity since other institutions such as the school and the church were not readily available.

The family, then, was the principal unit of social organization in the colonies and the most important agency of popular education; and it assumed an educational significance that went considerably beyond that of its English counterpart. Whereas England had by the 1640s and 1650 s placed churches within reach of virtually every household, schools within the reach of most, and universities within the reach of at least the more ambitious and able, the colonies were only beginning in those directions. Hence, while metropolitan families could take for granted the ready availability of other institutions to assist in the educational task, colonial families could not. As a result, the colonial household simply took unto itself, by force of circumstance, educational responsibilities that the English family commonly shared with other agencies (Cremin, 1970: 135).

Indeed, even when local churches were available nearby, the New England Puritans before the 1660 s continued to emphasize the role of the family over that of the church in the catechizing of children and servants (Axtell, 1974). ${ }^{4}$

For the New England Puritans, the primary educator in the family was the father who as the head of the household was expected to catechize his own children and servants. While the mother might assist the father in this task, it was his primary responsibility (Moran and Vinovskis, forthcoming). ${ }^{5}$ After the Anne Hutchinson turmoil in the 1630 s, the $\mathrm{Pu}-$ ritan leaders were reluctant to entrust religious instruction to females. ${ }^{6}$ In addition, the appropriateness of the father as the principal educator was reinforced by the fact that husbands usually were more literate than wives - an estimated sixty percent of men among the early settlers could sign their wills while only about thirty percent of women were able to do so (Lockridge, 1974). Indeed, Auwers (1980) found that female literacy in seventeenthcentury Windsor, Connecticut was associated with the literacy of the father but not that of the mother

While parents were expected to teach their own children how to read and to catechize them, Massachusetts also passed legislation in 1647 requinng communities of one hundred or more households to maintain a grammar school and those of fifty or more households to establish schools to teach reading and writing. As in England, this legislation was intended to complement rather than to replace parental efforts in the home (Cohen, 1974; 
Cremin, 1970). Interestingly, Murphy (1960) found that in the first decade after the enactment of this law, only a third of the eligible towns complied with the requirement to establish petty or dame schools to teach elementary reading and writing while all eight of the towns required to maintain a grammar school did so. Thus, by the mid-seventeenth century, many of the larger Massachusetts communities provided some formal schooling for their inhabitants even though the emphasis was still on having parents educate and catechize their own household members.

Bailyn was correct to point to a crisis in Puritan society in the seventeenth century. The exact nature of that crisis, however, may have been slightly different than he had envisioned. As Bailyn observed, church membership declined in the seventeenth century and this led many Puritans to conclude that there was a serious decline in religious commitment in their society. While more recent scholarship (Hall, 1972; Moran, 1979, 1980; Pope, 1969) on Puritan church membership portrays a more complex picture of declension than the one suggested by Miller (1953), there is little doubt that many Massachusetts residents in the seventeenth century were deeply concerned about this trend.

Rather than seeing the enactment of these early school laws as evidence of the disintegration of the stable family in New England, it is probably more accurate to see it as a reflection of the attempts to promulgate correct religious views and to overcome the growing indifference of many families toward religion and home education. In the aftermath of the Antinomian crisis, Puritan ministers and magistrates were very anxious about threats to their religion and wanted to make sure that correct doctrine was being taught in schools and at home (Foster, 1984; Hall, 1968). They also were reacting to the ap- parent growing indifference or unwillingness among many parents to catechize their own children (Axtell, 1974). As a result, the Puritans not only required the establishment of schools in towns and the use of approved catechisms in the home, they were even willing sometimes to remove children from households which failed to educate and catechize them properly (Morgan, 1966).

In addition to the apparent overall decline in church membership, there was simultaneously a growing unwillingness of adult males to join the church in the mid-seventeenth century. Church membership became increasingly feminized, although control of the congregation still rested in the hands of male elders and deacons (Moran, 1979, 1980; Moran and Vinovskis, 1982). As a result, many of the male heads of the households were unwilling or no longer could be entrusted to educate and catechize their children and servants as they were not church members. This led to a variety of experiments to provide alternative sources of education, including more emphasis on catechism within the churches and an increasing reliance on schoolteachers (Axtell, 1974; Hall, 1972). It also led in the longrun to a greater reliance on the mothers, who continued to join the church in larger proportions than their husbands, to educate and catechize their children - thus increasing the need for educating women beyond the simple ability to read the Bible by themselves. Not surprisingly, the literacy rate for women increased substantially during the colonial period from about $30 \%$ in the early seventeenth century to $60 \%$ at the end of the eighteenth century (Lockridge, 1974).

If there is general agreement that the rates of literacy for both males and females in colonial New England increased, there is considerable disagreement over how this was achieved. Lockridge (1974), 
Daniels (1979), Auwers (1980), and Soltow and Stevens (1981) argue that the expansion in the number of schools in New England as the population density increased led to the rise in literacy. Lockridge (1974: 58) specifically dismisses home education as a possible explanation for the rise in literacy.

Some scholars (Moran and Vinovskis, forthcoming) have questioned the rejection of household education as a possible factor in increased literacy by pointing out that since the emphasis in Puritan religion was on being able to read the Bible, it is not surprising that many girls might be taught to read but not to write whereas the boys were more likely to be educated in both skills as part of their career preparation. In addition, Auwers' (1980) study of literacy suggests an increase in female literacy even in those sections of Windsor which were far removed from any schools. Furthermore, some educational historians (Cohen, 1974) have argued that opporunities for formal education may have declined for many children in the eighteenth century even though literacy was increasing during these years. ${ }^{8}$ Thus, the relative role of the household or the schools in the education of colonial Americans in the late seventeenth and eighteenth centuries still awaits further research.

The manner of maintaining and running schools in colonial New England varied considerably. As Bailyn (1960) pointed out, the expectation that rents from lands granted for educational purposes would produce sufficient income for schooling did not materialize. Therefore several other sources of income were used, such as tuition, subscription, and increasingly annual grants from the town treasury (Cohen, 1974; Cremin, 1970; Murphy, 1960). The direct costs to parents of educating children also differed among Massachusetts communities. In some towns all pupils attended school without any additional expense while in others all students except the children of the poor paid tuition.

Taxpayers were reluctant to assume the costs of elementary education and town meetings frequently reaffirmed the responsibility of parents for educating their own children. Yet once schools were established, especially at the expense of all taxpayers, parents were quite willing to send their children to these schools rather than teaching them to read and write at home (May and Vinovskis, 1977). Thus, even though the general increase in literacy in colonial America made parents more capable of training their children at home, most parents preferred, whenever possible, to send their offspring to public or private schools.

The Puritans emphasized education more than most other colonists (Cohen, 1974; Cremin, 1970, 1976; Morgan, 1966). New England led the rest of the colonies in literacy and schooling (Cremin, 1970; Lockridge, 1974). Although efforts were made to establish schools in the South, they failed due to the greater dispersion of population and the lack of sustained financial support locally (Cohen, 1974). Educating children was more difficult in the South because very high rates of mortality in the early decades of settlement made family life very unstable (Beales, 1985; Earle, 1979; Rutman and Rutman, 1979). Nevertheless, southern parents frequently tried to provide for the education of their children by setting aside funds for schooling in their wills (Carr and Walsh, 1977).

As southern society became more settled and family life more stable after mortality rates declined in the second half of the seventeenth century, it became easier to plan and provide for education. Yet southern parents did not seem to value education as much as their northern coun- 
terparts. Indeed, some planter sons were educated more as a sign of family respectability and achievement than as reflection of their commitment to learning (Smith, 1980).

Rather than trying to establish schools, most planters were content to hire tutors to educate their sons in the home and then send them abroad or North for a university education. While planters also provided for the training of their daughters, they usually did not encourage education much beyond reading and writing (Smith, 1980). Since the South did not develop an extensive system of schools, most children of less wealthy parents received only a rudimentary education and many did not even acquire literacy (Cohen, 1974; Cremin, 1970, 1976).

\section{NINETEENTH-CENTURY PATTERNS AND PRACTICES}

Analyzing the relationship between family and schooling has been a central concern for students of American colonial history but not for investigators of nineteenth-century educational or family development. One explanation for the lack of scholarly attention to families and schooling in the nineteenth century is that children did receive most of their education in schools. New England colonists stressed the importance of educating and catechizing children in the home; nineteenth-century parents assumed that learning to read and write would occur in a classroom. The role of parents, especially the mother, was not ignored in the socialization of the child in the nineteenth century, but they were not seen as an alternative to sending children to school. Therefore, it is not surprising that most analysts of antebellum education have devoted relatively little attention to the family.

Interpretations of family-school inter- actions are influenced by how one explains increases in public schooling during the nineteenth century. Since the late 1960s, a group of revisionist scholars have argued that capitalists, in order to minimize labor unrest during industrialization, imposed education upon largely unwilling and uninterested working-class families. The revisionists tend to emphasize the tension between the interests of working-class families and the schools established by the capitalists; they also locate the rise of mass education in the decades prior to the Civil War and associate that increase with the industrializing Northeast (Bowles and Gintis, 1976).

While the revisionist perspective has contributed to our understanding of antebellum education, especially by challenging many of the more traditional explanations and stimulating further research, it has not provided a satisfactory account either of educational developments or the reactions of families to schooling. The terms educational "expansion" and "reform" are often used interchangeably by the revisionists - even though they often refer to separate developments and which may have occurred in different time-periods (Vinovskis, 1985a). For example, contrary to the revisionist argument that mass education emerged in Massachusetts in the middle third of the nineteenth century, widespread schooling in that state originated much earlier and was influenced by Puritan religion as well as the establishment of a new republic which required a more educated citizenry (Kaestle and Vinovskis, 1980; Kerber, 1980; Norton, 1980).

We also need to recognize that there were large regional differences in schooling and literacy in nineteenth-century America (Kaestle, 1983). The South continued to trail the North in schooling and literacy -indeed in some Southern states on the eve of the Civil War, nearly $20 \%$ of 
white adult females were illiterate whereas almost all native-born Northern white adult females were literate (Vinovskis and Bernard, 1978).$^{10}$ Furthermore, the largest gains in education in the decades before the Civil War occurred in the Midwest even though that area was still mainly agricultural and had not experienced extensive industrialization as suggested by the revisionist model of educational development (Fishlow, 1966; Soltow and Stevens, 1981).

Rather than seeing common school education simply imposed upon workingclass families, it is more accurate to acknowledge the strong, if not sometimes excessive and misguided, faith in public schooling among all segments of nineteenthcentury New England society (Fuller, 1982; Kaestle, 1983; Katznelson and Weir, 1985; Mirel, 1981). While the leadership of educational reforms undoubtedly came from a smaller and more elite segment of the population, including not only capitalists but especially others like the clergy, there was widespread public support for common schools-even though the shift from private to public education meant that taxpayers had to shoulder a heavier burden (Vinovskis, 1985a).

While some infer an inevitable conflict between the family and schools as the latter multiplied in number and scope during the nineteenth century and seemingly competed with parents for the attention of children, the process was actually more complementary. The role of women in the raising of their children, for example, expanded considerably during the antebellum period (Kuhn, 1947; Ryan, 1981). Mothers were now seen as the natural and logical caretakers of their young children since fathers continued to reduce their active involvement in the socialization of the child (Demos, 1982; Vinovskis, forthcoming [b]). The doctrine of separate spheres rationalized and reinforced the growing expectations and obligations of the mother to her children even though schools were playing a larger role in the formal instruction of the child than in the colonial period (Cott, 1977; Norton, 1980). Furthermore, as women replaced men as the school teachers for young children, any apparent separation between the home and the school was minimized as women continued their primary role of educating the young (Bernard and Vinovskis, 1977; Fitts, 1979; Boylan, 1985; Hoffman, 1981; Morain, 1980).

Parents did not oppose the expansion of schools in principle although in practice they often voted against any increases in their taxes for public education. According to the Massachusetts State Law of 1789 , children enrolling in grammar schools were expected already to be able to read and write. Some of the citizens of Boston complained that since the community did not provide public primary schools, children of poor parents could not afford to go to private schools to learn to read and write and therefore were in effect excluded from the grammar schools (Schultz, 1973). The Boston School Committee appointed a subcommittee in 1817 to investigate the issue. The subcommittee reaffirmed the traditional, colonial view that parents could and should educate their own children in the home rather than in a public school (Wightman, 1860).

Although the Boston School Committee emphasized the role of parents in teaching children how to read and write, it acknowledged that most parents who could afford to send their children to private schools were already doing so. After some heated discussions, the Committee relented and established in 1818 a few free primary schools for children ages four to six. The demand for these public primary schools was much greater than had been anticipated. Not only did the children from poor families enroll in the new pub- 
lic schools, but also many whose parents were more affluent and had been sending their children to private schools (Wightman, 1860). Thus, while parents as taxpayers sometimes opposed an expansion of public schools, as individuals charged with the primary responsibility for the education of their young children they were quite willing in the nineteenth century to send their children to public schools to learn how to read and write.

The schools did not always try to expand their influence over young children. Indeed, it was often the parents who insisted that schools open their doors to very young children when many school teachers and administrators preferred to have them remain at home. During the 1820 s the idea of schools for infants was imported from Europe as a means of helping children of poor or broken families to overcome their lack of adequate training in the home. Infant schools received favorable notices in Boston newspapers as a way of helping poor children (Boston Recorder and Scriptual Transcript, 1829). When middle-class parents realized that the children of the poor might derive an advantage over others by going to infant schools, they were quick to take advantage of these new institutions for their own children (Ladies Magazine, 1829: 89-90).

Despite the growing interest in early education, public schools were reluctant to accept children ages two or three in their classrooms. The considerable influence that parents had on local school boards, however, meant that educators often could not exclude young children-especially since there was strong pedagogical support for the infant schools among some experts in the late 1820 s and early 1830s. As a result, it is estimated that nearly $40 \%$ of three-year-olds in Massachusetts may have been enrolled in public and private schools (May and Vinovskis, 1977).
The enthusiasm for infant schools among experts did not last long. Medical opinion, based upon the increasingly popular idea that mental and physical development in the early stages of childhood must be carefully balanced, turned sharply against early education and the infant schools. Amariah Brigham, a noted nineteenth-century physician, attacked early childhood education:

\footnotetext{
Many physicians of great experience are of the opinion, that efforts to develope [sic] the minds of the young children are very frequently injurious; and from instances of disease in child ren which I have witnessed, I am forced to believe that the danger is indeed great, and that very often in attempting to call forth and cultivate the intellectual faculties of children before they are six or seven years of age, serious and lasting injury has been done both to the body and the mind....

I beseech parents, therefore, to pause before they attempt to make prodigies of their own children. Though they may not destroy them by the measures they adopt to effect this purpose, yet they will surely enfeeble their bodies, and greatly dispose them to nervous affections. Early mental excitement will serve only to bring forth beautiful, but premature flowers, which are destined soon to wither away, without producing fruit (Brigham, 1833: 15, 55).
}

Brigham's strong admonitions against early education were received favorably in popular magazines and repeated in many childrearing manuals (Kaestle and Vinovskis, 1980). Simultaneously, schoolteachers and administrators who had opposed the presence of such young children in the classroom earlier as an unnecessary and unwarranted disruption to the rest of the class, now joined forces with those anxious to keep young children out of the schools. Nevertheless, many parents who had been brought up believing that children could and should be taught to read at a very young age refused to keep their young children at home. Since many local school committees, especially in the 
smaller communities, were still reluctant to refuse admission to children whose parents continued to insist that early education was beneficial, the process of eliminating young children from classrooms took more than a decade to complete (Kaestle and Vinovskis, 1980). ${ }^{11}$

The establishment and demise of infant education illustrates several points about the relationship between families and schools in the nineteenth century. Parents in the early nineteenth century were eager to enroll very young children in school because they thought children had the mental capacity to learn to read at ages three or four. As long as parents felt that schools could teach their children to learn to read at an early age, they were willing to relinquish them to the care of teachers rather than educating them at home. Although schoolteachers and administrators often opposed sending young children into the classroom, antebellum local school committees were reluctant to establish and enforce minimum ages for school attendance in the face of strong parental objections. In addition, there was a considerable time-lag between when prominent physicians and educators declared early childhood education dangerous and when most parents agreed by keeping their young children at home. Finally, the gradual expulsion of young children from the classrooms meant that mothers played a larger and longer role in the socialization of their young children in the home.

If many early nineteenth-century parents were eager to send their children to school, they were more reluctant to have them stay in school beyond the time necessary to obtain a basic common school education. Unfortunately, there is very litthe analysis of the relative role of the student or their parents in the decision to leave school. Most scholars seem to simply assume that the parents exercised the most influence in deciding when their children would end their schooling; some recent work on high school attendance in the late nineteenth century, however, suggests that the experiences of the students themselves in school may have influenced that decision. Perlmann (1985b) has found that the grades students received in high school were a better predictor of whether or not they decided to stay in school than the occupation of their father. ${ }^{12}$

Historians of colonial education have found it difficult to analyze the characteristics of students and their families because of the lack of readily available information. Scholars of nineteenth-century education, however, have been more successful because they can ascertain the characteristics of school attendance in the decennial federal manuscript censuses from 1850-1880 and 1900-1910 which asked each person under twenty if they had attended any school during the past year.

The classic work by Thernstrom (1964) on school attendance in Newburyport, Massachusetts found that Irish Catholics were much less likely to keep their children in school than native-born Protestants. Thernstrom argued that Irish parents, eager to purchase their own home, sacrificed the future social mobility of their children by sending them into the labor force. Thernstrom's emphasis on the ethnicity and religion of the Irish as the explanation for the differential school attendance rates has been challenged by revisionists such as Katz (1975) who interpret variations in school attendance as class differences. ${ }^{13}$ More recent studies (Kaestle and Vinovskis, 1980; Katz and Davey, 1978), using more sophisticated statistical techniques such as multiple classification analysis, have found that both ethricity and occupation influence the likelihood of remaining in school. Furthermore, the argument that Irish 
families prematurely sent their children into the labor force in order to purchase a home has not been substantiated. In fact, several investigators (Katz, 1982; Perlmann, 1985a) have found a positive rather than negative relationship between home ownership and school attendance. ${ }^{14}$

Most studies of the influence of family characteristics on school attendance focus on the attributes of the head of household (i.e., ethnicity or occupation). Yet this provides only a limited sense of the needs and resources of the family as a whole. Some scholars (Kaestle and Vinovskis, 1980) have tried to develop a work/consumption index which takes into account the number of workers and consumers in each family according to information from the federal manuscript censuses. Yet the results from these investigations do not show a strong relationship between school attendance and the economic well-being of the family as a whole-perhaps suggesting that the particular work/consumption indices may not be an accurate reflection of the overall economic circumstances of the family. ${ }^{15}$

While studies of school attendance using census data are useful, they do not have the type of detailed financial information one would like to have in order to study the impact of the economic circumstances of the family on the school attendance of its children. Therefore, historians are now turning to the more detailed industrial household budget data from the late nineteenth century. Using the household budgets of textile workers in 1890 , Angus and Mirel (1985) did find that the economic situation of the family played an important part in predicting whether or not a child stayed in school.

The frustration of school reformers in getting some children, especially those of immigrant parents, to go to school led to the passage of compulsory school atten- dance laws in the nineteenth century. Massachusetts led the nation in the enactment of legislation in the mid-nineteenth century which required children under fifteen years of age working in manufacturing establishments to attend school at least three months each year. Despite repeated exhortations by these reformers to the parents and manufacturers to comply with the laws as well as the attempt to hire truant officers in several communities, there was such widespread evasion of the compulsory school attendance laws in the nineteenth century that most contemporaries doubted that they had much of an impact upon school going (Kaestle and Vinovskis, 1980).

Many nineteenth-century Americans were convinced that cities were destroying the traditional family (Boyer, 1978). Conservatives also bemoaned the disestablishment of the state church and the rise of less orthodox religious groups such as the Unitarians (Howe, 1970; Turner, 1985). As a result, many educational reformers saw urban public schools replacing the family and the church as the primary means of educating children. Thus, while nineteenth-century educational reformers continued to speak of the complimentary roles of the family, the church, and the school in the proper upbringing of children, many of them openly or secretly feared that in fact the school was the last bastion for civilizing youths growing up in the cities (Schultz, 1973). ${ }^{16}$

While considerable research has been done on trends in nineteenth-century schooling as well as on the individual family characteristics of students, much less work is available on parent-school relationships. Many of the studies which do look at parent-school interactions focus on the tension between school reformers who wanted to professionalize teaching and advocated giving town school committees more control, and parents who 
favored having local school district committees making decisions since they were more responsive to the particular needs of that area (Katz, 1971). Gradually the proponents of centralization in Massachusetts, for example, won control of the public schools in the second half of the nineteenth century.

In the rural Midwest, however, parents exercised more control over their public schools longer since state governments gave local districts corporate powers with only minimal restrictions on how they were to be administered. The governance of these small school districts involved a high proportion of local families and provided them with an important sense of participation and power (Fuller, 1982).

Professional educators objected to the decentralization of education in the rural Midwest, but farmers welcomed it and resisted efforts to change it. While nineteenth-century educators pointed to the inefficiencies and ineffectiveness of that decentralized system, at least one researcher (Fuller, 1982) argues that the centralization of schooling at the township level in the Midwest hurt education overall by reducing local interest and support for it.

If town school committees and administrators clashed with parents over the control of hiring teachers and running local schools, they were also anxious to involve the parents in the classroom. Nineteenth-century educators frequently complained about parental apathy or indifference to schooling which permitted or even encouraged their children to be absent or tardy from school. In addition, teachers recognized the need for parental involvement in order to stimulate better performances by students and therefore encouraged parents to attend classes and special examinations. Most nineteenthcentury teaching manuals advised teach- ers to encourage parents to visit classrooms regularly:

The teacher should encourage parents frequently to visit his school. There is almost everywhere too great backwardness on the part of parents to do this duty. The teacher should early invite them to come in. It is not enough that he do this in general terms. He may fix the time, and arrange the party, so that those who would assimilate, should be brought together. It will frequently be wise to begin with the mothers, where visitation has been unusual. They will soon bring in the fathers. As often as they come they will be benefited. When such visits are made, the teacher should not depart from his usual course of instruction on their account... (Page, 1859: 251-252).

If educators sought parental cooperation and participation in the classroom, they were also aware of the conflicts which arose. Immigrant parents, especially those who were Catholic, often complained bitterly that their children were being indoctrinated in Protestantism in the public schools (Angus, 1980a; Ravitch, 1974). This often led to the removal of foreign-born children from the public schools and the establishment of parochial schools at great additional expense to the parents. Yet in some cities such as St. Louis, school reformers allowed students to be taught in German in order to attract more support for the public schools (Troen, 1975).

Parents also often objected to the type and extent of discipline imposed upon their children in the classroom as well as how and what they were taught. During the course of the nineteenth century parents reluctantly and often unhappily relinquished much of their involvement and influence over activities within the classroom.

In general, parents in nineteenth-century America wanted schools to take custody of their children, and they wanted schools to 
train their children in basic skills and attitudes. The eventual price that they paid was the loss of authority and control over their children's education. The trade-off was made. The state successfully exerted its right to discipline all children in values that served, first and foremost, the operational necessities of the school, but that also served the social leaders' image of appropriate adult behavior and the parents' image of appropriate childhood behavior. Despite the apparent grounds for consensus, this differentiation of function and shift of authority to the school ultimately produced not just different, but substantially contrary goals.

Elements of antagonism between school and family did not end with a new nineteenth-century equilibrium; they persist today. Clearer boundaries did not necessarily eliminate conflict, but in some ways merely prevented its expression. Compulsory attendance laws, the professionalization of teaching and administration, the development of pedagogical expertise, and the construction of fortress-like urban schools--these helped to insure that parents would interfere less: they did not insure that parents would feel happier or be better served (Kaestle, 1978: 15).

Thus, parents during the nineteenth century increasingly turned their children over to the schools even though it sometimes meant that they had to accept educational and disciplinary practices which they did not favor. Nevertheless, the interactions between parents and schooling continued to influence the nature of the nineteenth-century educational system since schoolteachers and administrators in most communities still were not sufficiently powerful simply to ignore the demands of parents.

\section{CONCLUSION}

Throughout human history, the family has played an important role in the socialization of its young. As civilizations developed, there was an increasing tendency to supplement the efforts of the family in the education of its young through other institutions such as churches and schools. The growth of these additional and alternative institutions of education reflect in large measure the recognition that the task of training the young is so vital to the interests of society that it cannot be entrusted exclusively to the family.

The family was an important source of education for children in colonial and nineteenth-century America. But from the very beginning churches and schools were directed to assist parents in the socialization of the young. Indeed, by the mid-nineteenth century, the role of the schools had expanded to such an extent that many of the educational tasks initially assigned to parents, such as teaching children the alphabet and how to read, became the responsibility of the schools.

Throughout the seventeenth, eighteenth, and nineteenth centuries, both parents and schools played an important part in the education of young Americans. While historians of the family and of education have frequently acknowledged these complementary, if not sometimes conflicting, institutions in the training of the young, very little effort has been made to examine the interactions between them. Despite Bailyn's call twenty-five years ago for a more comprehensive approach to the study of education, few historians have responded directly to that challenge. Nevertheless, as this article suggests, many of the particular components of a broader interpretation of the role of parents and schools in the education of the young now have been completed and prepare the way for a more dynamic and family-oriented analysis of the education of children in early America.

\section{ACKNOWLEDGMENTS}

I want to thank David Angus, Raymond Grew, Carl Kaestle, Jeffrey Mirel, Gerald 
Moran, and James Turner for very useful comments on an earlier version of this essay.

\section{NOTES}

1. For an introduction to recent work on family history, see Degler (1980), Gordon (1978), Ryan (1982), and Vinovskis (forthcoming[a]). For deve]opments in educational history, see Angus (1983), Cremin (1970, 1980), Graff (1977), and Vinovskis (1983, 1985a). There are two earlier essays (Angus, 1980b; Cremin, 1978) on the relationship between the family and education that are quite useful.

2. Although there are no specific references in Bailyn (1960) to the Handlin volume (1951), Bailyn probably drew upon some of the general ideas espoused by Handlin - especially the chapters which dealt with the reactions of parents and children to the New World.

3. While critics (Vinovskis, 1971) quarrel with some of Greven's methodology and findings, no one has contested his assertion that family life in New England was relatively stable. Similar results have been reported (Demos, 1970; Lockridge, 1970) for other communities in seventeenth-century Massachusetts.

4. The most detailed and comprehensive treatment of the role of education and the family among the New England Puritans is still Morgan (1966). While his account discusses the difficulties that Puritans experienced in trying to get families to fulfill their responsibilities, it does not convey the sense of disintegration and instability present in Bailyn's (1960) account.

5. Hiner (1973: 12) points out that "hardly any attention was devoted to mothers in seventeenthcentury recitations of parental duties." Indeed, "if the Puritan father had a relatively equal teaching partner, it was not his wife, but his minister" (Hiner, 1973: 13).

6. On the changing role of women and religion during the seventeenth century, see Dunn (1980), Koehler (1980), Moran (1979, 1980), Moran and Vinovskis (1982, forthcoming), and Ulrich (1980, 1982).

7. According to Hiner (1973), seventeenthcentury Puritans did not emphasize the importance of the lower schools. Beginning in the 1690s, however, Cotton Mather and others began to stress the need for these lower schools as a way of cultivating civility among unregenerate children.

8. Whether or not educational facilities in creased or decreased proportionate to the population in eighteenth-century New England is not clear.
Part of the confusion stems from the fact that much of the evidence of school decline comes from data on grammar schools. Yet Teaford (1970) argues that although classical grammar schools did decline in the late seventeenth and eighteenth centuries, they were replaced by other secondary schools which taught English. According to Teaford, there is a transformation of the nature of secondary education in Massachusetts prior to the American Revolution rather than a decrease in interest in education. Thus, the entire issue of the relative availability of elementary schools to teach basic skills to children in the eighteenth century still awaits further research.

9. There is considerable debate over the exact meaning of the term "revisionist" since it encompasses a group of scholars who often disagree among themselves on important aspects of educational development. For a discussion of the term, see Ravitch (1978) and Katz (1976).

10. Relatively little has been written about education in the nineteenth-century South. For an introduction to some recent studies, see Burton (1985), Kett (1985), and Stowe (1985). On the educational experiences of slaves and freedmen, see Jones (1980), Webber (1978), and Wyatt-Brown (1985).

11. When kindergartens were established later, often very young children were excluded from attending them. In addition, kindergartens deliberately did not try to teach young children how to read (Finkelstein, 1985)

12. In general, there is very little concern among historians with the experiences of students in the classroom. For a good introduction to this issue, see Boylan (1985) and Finkelstein (1979). As an example of how nineteenth-century children learned to draw at home and in school, see Korzenik (1985).

13. Thernstrom's study of Newburyport education is now being revised by Vinovskis (1985b) who is analyzing the educational experiences of all children in that community rather than of just those who were the offspring of common laborers. Preliminary findings suggest that Thernstrom underestimated the extent of school attendance in Newburyport-even among the children of the common laborers he investigated.

14. Hogan (1985) maintains that home ownership and early school leaving are related in his study of Chicago, but he does not have any individuallevel data which would either support or refute that proposition.

15. The work/consumption index seems to predict the likelihood of women going into the labor force (Mason, Vinovskis, and Hareven, 1978), but does not explain school attendance. Since many 
nineteenth-century girls who dropped out of school stayed at home rather than entering the labor force, it may be that the processes of school leaving and entry into the paid labor force are not identical for females.

16. Public elementary and secondary schools were not the only institutions devised by nineteenthcentury Americans to cope with their perceived crisis of raising children in the cities. Child-reform advocates also established orphan asylums (Hawes, 1971), Sunday schools (Boylan, 1979), and reform schools (Brenzel, 1983; Schlossman, 1977) for helping children. For an interesting introduction and interpretation of these and other institutions for the care of children, see Finkelstein (1985).

\section{REFERENCES}

Allen, David Grayson. 1981. In English Ways: The Movement of Societies and the Transferral of English Local Law and Custom to Massachusetts Bay in the Seventeenth Century. Chapel Hill: University of North Carolina Press.

Angus, David L. 1980a. "Detroit's Great School Wars: Religion and Politics in a Frontier City, 1842-1853." Michigan Academician 12: 261-280. 1980b. "Families Against the System: Fifty Years of Survival, 1880-1930." Educational Considerations: 9-14. 1983. "The Empirical Mode: Quantitative History." Pp. 75-93 in John Hardin Best (ed.), Historical Inquiry in Education: $A$ Research Agenda. Washington, D.C.: American Educational Research Association.

Angus, David L. and Jeffrey E. Mirel. 1985. "From Spellers to Spindles: Work-Force Entry by the Children of Textile Workers, 1888-1890." Social Science History 9:123-143.

Ariès, Phillippe. 1962. Centuries of Childhood: A Social History of Family Life. Trans. Robert Baldick. New York: Vintage.

Auwers, Linda. 1980. "Reading the Marks of the Past: Exploring Female Literacy in Colonial Windsor, Connecticut." Historical Methods 4: 204-214.

Axtell, James. 1974. The School Upon a Hill: Education and Society in Colonial New England. New Haven, CT: Yale University Press.

Bailyn, Bernard. 1960. Education in the Forming of American Society. Chapel Hill: University of North Carolina Press.

Beales, Ross W.,Jr. 1985. "The Child in SeventeenthCentury America." Pp. 3-56 in Joseph M. Hawes and N. Ray Hiner (eds.), American Childhood: A Research Guide and Historical Handbook. Westport, CT: Greenwood Press.
Berkner, Lutz. 1972. "The Stem Family and the Developmental Cycle of the Peasant Household: An Eighteenth-Century Austrian Example." American Historical Review 77: 398-418.

Bernard, Richard M. and Maris A. Vinovskis. 1977. "The Female School Teacher in Antebellum America." Journal of Social History 3: 332-345.

Boston Recorder and Scriptural Transcript. July 9 , 1829.

Bowles, Samuel and Herbert Gintis. 1976. Schooling in Capitalist America: Educational Reform and the Contradictions of Economic Life. New York: Basic Books.

Boyer, Paul. 1978. Urban Masses and Moral Order in America, 1820-1920. Cambridge, MA: Harvard University Press.

Boylan, Anne M. 1979. "The Role of Conversion in Nineteenth-Century Sunday Schools." American Studies 20: 35-48.

1985. "Growing Up Female in Young America, 1800-1860." Pp. 153-184 in Joseph M. Hawes and N. Ray Hiner (eds.), American Childhood: A Research Guide and Historical Handbook. Westport, CT: Greenwood Press.

Brenzel, Barbara. 1983. Daughters of the State: A Social Portrait of the First Reform School for Girls in North America. 1856-1905. Cambridge, MA: M.I.T. Press.

Brigham, Amariah. 1833. Remarks on the Influence of Mental Cultivation and Mental Excitement Upon Health. 2nd ed. Boston.

Burton, Orville B. 1985. In My Father's House Are Many Mansions: Family and Community in Edgefield, South Carolina. Chapel Hill: University of North Carolina Press.

Carr, Lois Green and Lorena S. Walsh. 1977. "The Planter's Wife: The Experience of White Women in Seventeenth Century Maryland." William and Mary Quarterly, 3rd Series 34: 542-571.

Cohen, Sheldon S. 1974. A History of Colonial Education. 1607-1776. New York: Wiley.

Cott, Nancy F. 1977. The Bonds of Womanhood: "Women's Sphere" in New' England, 1780-1835. New Haven, CT: Yale University Press.

Cremin, Lawrence A. 1970. American Education: The Colonial Experience, 1607-1783. New York: Harper \& Row.

1976. Traditions of American Education. New York: Basic Books.

1978. "Family-Community Linkages in American Education: Some Comments on the Recent Historiography." Teachers College Record 79: 683-704 American Education: The National Ex. 
perience, 1783-1876. New York: Harper \& Row.

Daniels, Bruce C. 1979. The Connecticut Town: Growth and Development, 1635-1790. Middletown, CT: Wesleyan University Press.

Degler, Carl N. 1980. "Women and the Family." Pp. 308-326 in Michael Kammer (ed.), The Past Before Us: Contemporary Historical Writings in the United States. Ithaca, NY: Cornell University Press.

Demos, John. 1970. A Little Commonwealth: Family Life in Plymouth Colony. New York: Oxford University Press.

"The Changing Faces of Fatherhood: A New Exploration of American Family History." Pp. 425-445 in Stanley H. Cath, Alan R. Gurwitt, and John Munder Ross (eds.), Father and Child: Developmental and Clinical Perspectives. Boston: Little, Brown.

Dunn, Mary Maples. 1980. "Saints and Sinners: Congregational and Quaker Women in the Early Colonial Period." Pp. 27-46 in Janet Wilson James (ed.), Women in American Religion. Philadelphia: University of Pennsylvania Press.

Earle, Carville V. 1979. "Environment, Disease, and Mortality in Early Virginia." Pp. 96-125 in Thad W. Tate and David L. Ammerman (eds.), The Chesapeake in the Seventeenih Century: Essavs on Anglo-American Society and Politics. New York: Norton.

Finkelstein, Barbara. 1979. “Reading, Writing, and the Acquisition of ldentity in the United States: 1790-1860." Pp. 114-139 in Regulated Children. Liberated Children: Education in Psychohistorical Perspective. New York: Psychohistory Press.

1985. "Casting Networks of Good Influence: The Reconstruction of Childhood in the United States, 1790-1870." Pp. 111-152 in Joseph M. Hawes and N. Ray Hiner (eds.), American Childhood: A Research Guide and Historical Handbook. Westport, CT: Greenwood Press.

Fishlow, Albert. 1966. "The American Common School Revival: Fact or Fancy?" Pp. 40-67 in Henry Rosovsky (ed.), Industrialization in Two Systems: Essays in Honor of Alexander Gershenkron. New York: Wiley.

Fitts, Deborah. 1979. "Una and the Lion: The Feminization of District School-Teaching and its Effects on the Roles of Students and Teachers in Nineteenth-Century Massachusetts. Pp. 140157 in Barbara Finkelstein (ed.), Regulated Children, Liberated Children: Education in Psychohistorical Perspective. New York: Psychohistory Press.
Foster, Stephen. 1984. "English Puritanism and the Progress of New England Institutions, 16301660. " Pp. 3-37 in David Hall, John M. Murrin, and Thad N. Tate (eds.), Saints and Revolutionaries: Essays on Early American History. New York: Norton.

Fuller, Wayne E, 1982. The Old Country School. Chicago: University of Chicago Press.

Gordon, Michael. 1978. The American Family: Past, Present, and Future. New York: Random House.

Graff, Harvey J. 1977. “The 'New Math': Quantification, the 'New' History, and the History of Education." Urban Education 11: 403-440.

Greven, Philip J. Jr. 1970. Four Generations: Population. Land, and Family in Colonial Andover. Massachusetts. Ithaca, NY: Cornell University Press.

Hall, David D. (ed.). 1968. The Antinomian Controversy, 1636-1638: A Documentary History. Middletown, CT: Wesleyan University Press. 1972. The Faithful Shepherd: A History of the New England Ministry in the Seventeenth Century. Chapel Hill: University of North Carolina Press.

Handlin, Oscar. 1951. The Uprooted: The Epic Story of the Great Migrations that Made the American People. New York: Grosset and Dunlap.

Hawes, Joseph M. 1971. Children in Urban Society: Juvenile Delinquency in NineteenthCentury' America. New York: Oxford University Press.

Hiner, N. Ray. 1973. "The Cry of Sodom Enquired Into: Educational Analysis in SeventeenthCentury New England." History of Education Quarterly 13: 3-22.

Hoffman, Nancy. 1981. Woman's "True" Profession: Voices from the History' of Teaching. New York: Feminist Press.

Hogan. David J. 1985. Class and Reform: School and Society in Chicago, 1880-1930. Philadelphia: University of Pennsylvania Press.

Houlbrooke, Ralph A. 1984. The English Family, 1450-1700. London: Longman.

Howe, Daniel Walker. 1970. The Unitarian Conscience: Harvard Moral Philosophy. 1805-1861. Cambridge, MA: Harvard University Press.

Jones, Jacqueline. 1980. Soldiers of Light and Love: Northern Teachers and Georgia Blacks, 1865-1873. Chapel Hill: University of North Carolina Press.

Kaestle, Carl F. 1978. "Social Change, Discipline, and the Common School in Early NineteenthCentury America." Journal of Interdisciplinary' History 9:1-17. 
1983. Pillars of the Republic: Common Schools and American Society, 1780-1860. New York: Hill and Wang.

Kaestle, Carl F. and Maris A. Vinovskis. 1980. Education and Social Change in NineteenthCentury Massachusetts. Cambridge: Cambridge University Press.

Katz, Michael B. 1971. Class, Bureaucracy, and Schools. New York: Praeger.

1975. The People of Hamilton, Canada West: Family and Class in a Mid-Nineteenth Century City. Cambridge, MA: Harvard University Press.

1976. "The Origins of Public Education:

A Reassessment." History of Education Quarterly 16: $381-407$.

1982. "School Attendance in Philadelphia, 1850-1900." Working Paper, Organization of School, Work and Family Life in Philadelphia, 1838-1920 Project, University of Pennsylvania.

Katz, Michael B. and lan E. Davey. 1978. "School Attendance and Early Industrialization in a Canadian City: A Multivariate Analysis." Historl' of Education Quarterly 18: 271-293.

Katznelson, Ira and Margaret Weir. 1985. Schooling for All: Class, Race, and the Decline of the Democratic Ideal. New York: Basic Books.

Kerber, Linda K. 1980. Women of the Republic: Intellect and ldeology in Revolutionary America. Chapel Hill: University of North Carolina Press.

Kett, Joseph F. 1985. "Women and the Progressive Impulse in Southern Education." Pp. 166-180 in Walter J. Fraser, Jr., R. Frank Saunders, Jr., and Jon L. Wakelyn (eds.), The Web of Southern Social Relations: Women, Family, and Education. Athens: University of Georgia Press.

Koehler, Lyle. 1980. A Search for Power: The "Weaker Sex" in Seventeenth-Century' New England. Urbana: University of Illinois Press.

Korzenik, Diana. 1985. Drawn to Art: $A$ Nineteenth-Century American Dream. Hanover, NH: University of New England.

Kuhn, Ann L. 1947. The Mother's Role in Childhood Education. New Haven, CT: Yale University Press.

Ladies' Magazine 2. February 1829

Laslett, Peter. 1969. "Size and Structure of the Household in England Over Three Centuries." Population Studies 23: 199-223.

1972. Household and Family in Past Time, Cambridge: Cambridge University Press. 1977. Family Life and Illicit Love in Earlier Generations: Essays in Historical Sociology. Cambridge: Cambridge University Press.
Lockridge, Kenneth A. 1970, A New England Town: The First Hundred Years: Dedham, Massachusetts, 1636-1736. New York: Norton. 1974. Literacy in Colonial New England: An Enquiry into the Social Context of Literacy in the Early Modern West. New York: Norton.

Mason, Karen, Maris A. Vinovskis, and Tamara K. Hareven. 1978. "Women's Work and the Life Course in Essex County, Massachusetts, 1880." Pp. 187-216 in Tamara K. Hareven(ed.), Transitions: The Family and the Life Course in Historical Perspective. New York: Academic Press.

May, Dean and Maris A. Vinovskis. 1977. "A Ray of Millenial Light: Early Education and Social Reform in the Infant School Movement in Massachusetts, 1826-1840." Pp. 62-99 in Tarnara K. Hareven (ed.), Family and Kin in American Urban Communities, 1800-1940. New York: Watts.

Miller, Perry. 1953. The New England Mind: From Colony to Province. Cambridge, MA: Harvard University Press.

Mirel, Jeffrey. 1981. "The Matter of Means: The Campaign and Election for the New York Free Academy, 1846-1847." Journal of Midwest History 9: 134-155.

Morain, Thomas. 1980. "The Departure of Males from the Teaching Profession in NineteenthCentury lowa." Civil War History 26: 161-170.

Moran, Gerald F. 1979. "Religious Renewal, Puritan Tribalism, and the Family in SeventeenthCentury Milford Connecticut." William and Mary Quarterly, 3rd Series 36: 236-254.

1980. "'Sisters' in Christ: Women and the Church in Seventeenth-Century New England." Pp. 47-65 in Janet Wilson James (ed.), Women in American Religion. Philadelphia: University of Pennsylvania Press.

Moran, Gerald F. and Maris A. Vinovskis, 1982. "The Puritan Family and Religion: A Critical Reappraisal." William and Mary Quarterly, 3rd Series 39: 29-63.

Forthcoming. "The Great Care of Godly Parents: Early Childhood in Puritan New England." In John Hagen and Alice Smuts (eds.), History and Research in Child Development: In Celebration of the Fiftieth Anniversary of the Society. Chicago: University of Chicago Press.

Morgan, Edmund S. 1966. The Puritan Family: Religion and Domestic Relations in SeventeenthCentury New England. New York: Harper \& Row.

Murphy, Joanne Geraldine. 1960. "Massachusetts Bay Colony: The Role of Government in Education." Unpublished Ph.D. dissertation, Radcliffe College. 
Norton, Mary Beth. 1980. Liberty's Daughters: The Revolutionary Experience of American Women, 1750-1800. Boston: Little, Brown.

O'Day, Rosemary. 1982. Education and Society, 1500-1800: The Social Foundations of Education in Early Modern Britain. London: Longman.

Page, David P. 1859. Theory and Practice of Teaching: Or. The Motives and Methods of Good School-Keeping. 25th ed. New York: A.S. Barnes and Burr.

Perlmann, Joel. 1985a. "Curriculum and Tracking in the Transformation of the American High School: Providence, R.I., 1880-1930." Journal of Social History 19: 29-55.

1985b. "Who Stayed in School? Social Structure and Academic Achievement in the Determination of Enrollment Patterns, Providence, Rhode Island, 1880-1925." Journal of American History 72: 588-614.

Pope, Robert G. 1969. The Hatf-Way Covenant: Church Membership in Puritan New England. Princeton: Princeton University Press.

Powell, Sumner Chilton. 1963. Puritan Village: The Formation of a New England Town. Middletown, CT: Wesleyan University Press.

Prest, W.R. 1976. "Stability and Change in Old and New England: Clayworth and Dedham." Journal of Interdisciplinary History 6: 359-574.

Ravitch, Diane. 1974. The Great School Wars: New York City, 1805-1973. New York: Basic Books. 1978. The Revisionists Revised: A Critique of the Radical Attack on the Schools. New York: Basic Books.

Rutman, Darret B. and Anita H. Rutman. 1979. "Now-Wives and Sons-in Law': Parental Death in a Seventeenth-Century Virginia County." Pp. 153-182 in Thad W. Tate and David Ammerman (eds.), The Chesapeake in the Seventeenth Century: Essays on Anglo American Society and Politics. New York: Norton.

Ryan, Mary P. 1981. Cradle of the Middle Class: The Family in Oneida County, New York, 17901865. Cambridge: Cambridge University Press. 1982. "The Explosion of Family History." Reviews in American History 10: 181-195.

Schlossman, Steven L. 1977. Love and the American Delinquent: The Theory and Practice of Progressive Juvenile Justice, 1825-1920. Chicago: University of Chicago Press.

Schultz, Stanley K. 1973. The Culture Factory: Boston Public Schools, 1789-1860. New York: Oxford University Press.

Smith, Daniel Blake. 1980. Inside the Great House: Planter Family Life in Eighteenth-Century.
Chesapeake Society. Ithaca, NY: Cornell University Press.

Soltow, Lee and Edward Stevens. 1981. The Rise of Literacy and the Common School in the United States: A Socio-Economic Analysis to 1870. Chicago: University of Chicago Press.

Stone, Lawrence. 1964. "The Educational Revolution in England, 1560-1640." Past and Present 28: 41-80.

Stowe, Steven M. 1985. "The Not-So-Cloistered Academy: Elite Women's Education and Family Feeling in the Old South." Pp. 90-106 in Walter J. Fraser, Jr., R. Frank Saunders, Jr., and Jon L. Wakelyn (eds.), The Web of Southern Social Relations: Women, Family, and Education. Athens: University of Georgia Press.

Teaford, Jon. 1970. "The Transformation of Massachusetts Education, 1670-1780." History of Education Quarterly 10: 287-307.

Thernstrom, Stephen. 1964. Poverty and Progress: Social Mobility in a Nineteenth-Century City. Cambridge, MA: Harvard University Press.

Troen, Selwyn K. 1975. The Public and the Schools: Shaping the St. Louis System, 1838-1920. Columbia: University of Missouri Press.

Turner, James. 1985. Without God, Without Creed: The Origins of Unbelief in America. Baltimore: Johns Hopkins University Press.

Ulrich, Laurel Thatcher. 1980. "Vertuous Women Found: New England Ministerial Literature, 1668-1735." Pp. 67-87 in Janet Wilson James (ed.), Women in American Religion. Philadelphia: University of Pennsylvania Press.

1982. Good Wives: Images and Reality in the Lives of Women in Northern New England, 1650-1750. New York: Alfred A. Knopf.

Vinovskis, Maris A. 1971. "American Historical Demography: A Review Essay." Historical Methods Newsletter 4: 141-148.

1983. "Community Studies in Urban Educational History: Some Methodological and Conceptual Observations." Pp. 287-304 in Ronald W. Goodenow and Diane Ravitch (eds.), Schools in Cities: Consensus and Conffict in American Educational History. New York: Holmes and Krier.

1985a. The Origins of Public High Schools: A Reexamination of the Beverly High School Controversy. Madison: University of Wisconsin Press.

1985b. "Patterns of High School Attendance in Newburyport, Massachusetts in 1860." Unpublished paper presented at the American Historical Association Annual Meeting, New York City. 
Forthcoming(a). "The Historian and the Life Course: Reflections on Recent Approaches to the Study of American Family Life in the Past." In David Featherman and Richard Lerner (eds.), Life-Span Development and Behavior, vol. 8.

Forthcoming(b). "Young Fathers and Their Children: Some Historical and Policy Perspectives." In Arthur Elster and Michael Lamb (eds.), Teenage Fathers.

Vinovskis, Maris A. and Richard M. Bernard. 1978. "Beyond Catherine Beecher: Female Education in the Antebellum Period." Signs 3: 856-869.
Webber, Thomas L. 1978. Deep Like the Rivers: Education in the Slave Quarter Community, 1831-1865. New York: Norton.

Wightman, Joseph M. 1860. Annals of the Boston Primary School Commitlee From Its First Establishment in 1818 to Its Dissolution in 1855. Boston.

Wyatt-Brown, Bertram. 1985. “Black Schooling During Reconstruction." Pp. 146-165 in Walter J. Fraser, Jr., R. Frank Saunders, Jr., and Jon L. Wakelyn (eds.), The Web of Southern Social Relations: Women, Family, and Education. Athens: University of Georgia Press. 